University of Nebraska - Lincoln

DigitalCommons@University of Nebraska - Lincoln

Faculty Publications, Department of Psychology

Psychology, Department of

2008

\title{
Basic and Applied Issues in Eyewitness Research: A Münsterberg Centennial Retrospective
}

\author{
Brian H. Bornstein \\ University of Nebraska-Lincoln, bbornstein2@unl.edu \\ Christian Meissner \\ University of Texas at El Paso
}

Follow this and additional works at: https://digitalcommons.unl.edu/psychfacpub

Part of the Psychiatry and Psychology Commons

Bornstein, Brian H. and Meissner, Christian, "Basic and Applied Issues in Eyewitness Research: A Münsterberg Centennial Retrospective" (2008). Faculty Publications, Department of Psychology. 337. https://digitalcommons.unl.edu/psychfacpub/337

This Article is brought to you for free and open access by the Psychology, Department of at DigitalCommons@University of Nebraska - Lincoln. It has been accepted for inclusion in Faculty Publications, Department of Psychology by an authorized administrator of DigitalCommons@University of Nebraska - Lincoln. 
Published in Applied Cognitive Psychology 22 (2008), pp. 733-736; doi 10.1002/acp.1478 Copyright

C 2008 John Wiley \& Sons, Ltd. Used by permission. http://www.interscience.wiley.com

Introduction to a special issue on "Basic and Applied Issues in Eyewitness Research: A Münsterberg

Centennial Retrospective"

\title{
Basic and Applied Issues in Eyewitness Research: A Münsterberg Centennial Retrospective
}

\author{
Brian H. Bornstein* and Christian A. Meissner** \\ * Corresponding author; Department of Psychology, 238 Burnett Hall, University of \\ Nebraska-Lincoln, Lincoln, NE 68588-0308 USA; email bbornstein2@unl.edu \\ ** University of Texas at El Paso, USA
}

Whether memory research should emphasize fundamental psychological theory in well-controlled laboratory settings (i.e. "basic" research) or practical questions in naturalistic settings (i.e. "applied" research) is a recurrent question in the field. The debate became especially prominent with the advent of the "everyday memory movement" in the 1980s (e.g. Banaji \& Crowder, 1989; Neisser, 1978, 1991), but it dates back to the origins of experimental psychology itself (i.e. the basic approach espoused by Wundt and Titchener vs. the more applied perspective taken by Külpe, Ebbinghaus, Binet, James and others). The debate is particularly relevant to the subarea of eyewitness memory, which has such obvious implications for the legal system.

Hugo Münsterberg, who was one of the earliest researchers on eyewitness memory, is probably the first figure to advocate strongly for a wider reliance by the courts on psychological research (Münsterberg, 1908; others, such as Binet and Freud, made similar, albeit less forceful, recommendations). Münsterberg's efforts were largely rebuffed (Wigmore, 1909), and since that time, there have been repeated calls for the courts to take eyewitness research (indeed, all social science research) more seriously, accompanied by a range of judicial responses ranging from ready acceptance to outright rejection (Monahan \& Walker, 2005). Nor are all psychologists of one mind on this issue. Indeed, even Münsterberg himself, who is widely regarded as one of the founders of applied psychology, at times urged caution in applying psychological research findings to real-world problems (Münsterberg, 1898; see Benjamin, 2006).

The time is ripe to revisit this issue, for three main reasons. First, 2008 is the centennial of the publication of Münsterberg's seminal work, On the Witness Stand. Thus, it is an apt time to step back and reconsider some of the issues raised by Münsterberg and other early researchers, and to see how far the field as a whole has come in the last 100 years. A conference at John Jay College of Criminal Justice in March 2007 ("Off the Witness Stand") ex- 
plicitly raised these issues, and several of the present papers are an outgrowth of the conference and some of the themes - historical, theoretical and methodological - that were raised there.

Second, although the courts often remain skeptical of eyewitness research, it is gradually gaining acceptance by the American legal system (Benton, McDonnell, Ross, Thomas, \& Bradshaw, 2007; Technical Working Group for Eyewitness Evidence, 1999). In contrast to the gradual and somewhat halting infiltration of eyewitness research in the American legal system, the British system has moved forward with a variety of reforms and has developed through more cooperative efforts between law enforcement and researchers (see Bull, 1999). Despite these contrasting models of progress, there is still disagreement throughout the research community about the reliability of certain research findings and whether they have been sufficiently researched to be used in court or to be advocated in the context of policy reform (e.g. Benton et al., 2007; Kassin, Tubb, Hosch, \& Memon, 2001; Malpass, 2006; Penrod \& Bornstein, 2007). The disagreement often centers on issues of external and ecological validity (Penrod \& Bornstein, 2007), which is at the heart of the larger basic vs. applied debate (Banaji \& Crowder, 1989).

Third, the trend for greater acceptance of research findings by the legal system has, in the opinions of some observers, created a situation in which there is an overemphasis on practical questions, accompanied by a lack of theoretical relevance. For example, some have suggested that research on the use of simultaneous vs. sequential lineups has progressed from a largely practical perspective (e.g. "diagnostic value"; see Wells \& Olson, 2002) and has lacked a full understanding of the psychological mechanisms that may be influenced by the shift in lineup method (Clark, 2003; Clark \& Davey, 2005; Gronlund, 2004, 2005; McQuiston-Surrett, Malpass, \& Tredoux, 2006; Meissner, Tredoux, Parker, \& MacLin, 2005). In other words, there is evidence that the pendulum is swinging too far in the applied direction. Although there is a place for psycholegal research that is primarily theoretical or primarily applied, the best psycholegal research addresses important legal questions while simultaneously advancing psychological theory (e.g. Wiener et al., 2002).

On the whole, then, it is a good time to revisit this debate. Applied Cognitive Psychology is an ideal venue for this endeavor, given the sorts of substantive and methodological issues that the journal typically considers. The articles contained in this special issue take a historical perspective in addressing the contemporary debate over the use of basic research methods and theory vs. applied approaches in research on eyewitness memory. It is easier for researchers to know where they are, as a field, when they have an appreciation of where they have been. By inserting Münsterberg into this debate, our goal is to examine what lessons we can draw from the past and to apply those lessons to contemporary issues. These issues concern both basic questions related to theory development (e.g. episodic memory, face recognition, social influence) and applied questions with implications for public policy.

The topics covered in this issue reflect the great variety of topics studied under the rubric of eyewitness memory, as well as the diversity of research methodologies and locations. Indeed, the papers describe research conducted both in and outside the laboratory, and they are written by scientists from the United States, Canada, the United Kingdom, Germany, South Africa and Australia. Münsterberg might have brought eyewitness research from Germany to the United States, but it has since spread worldwide.

In organizing the contents of the issue, we have used the heuristic of going from the general to the specific. All of the papers are informed by a historical perspective, in general, and Münsterberg's work in particular; but we begin with two papers that are ex- 
plicitly historical analyses and place On the Witness Stand in its historical context. Sporer accomplishes this by reminding readers of the wealth of eyewitness research being conducted in Europe in the late 19th and early 20th centuries, especially by the German psychologist William Stern; while Bornstein and Penrod do so by contrasting Münsterberg's work with that of his virtually unknown contemporary, G. F. Arnold.

The next three papers (Turtle et al.; Lane \& Meissner; Malpass et al.) broadly address the critical issues with which the field of eyewitness research grapples: should we be doing basic or applied research? Is it possible to do both at once, and do them well? Does (and can) research using divergent methodologies yield convergent findings? How much convergence, and how large a body of findings, is necessary to promote confident policy recommendations or to provide responsible and accurate expert testimony? While there are no easy answers to these questions, these papers will help ensure that we do not lose sight of these issues in conducting eyewitness research.

The four papers that follow (Clark; Deffenbacher; Brewer \& Weber; Memon et al.) continue this discussion by exploring a number of specific topics in greater detail. The topics considered in these papers include the application of mathematical models to understand eyewitness behavior, methodological challenges and concerns, and the influence of several estimator (e.g. stress, retention interval, confidence, decision latency) and system variables (e.g. lineup composition, lineup instructions). As with other papers in this issue, they address the basic and applied contributions of the research, and they identify areas where the literature yields fairly consistent findings, as well as areas where more work is needed.

The special issue concludes with a commentary by Gary Wells. Wells' own research on eyewitness memory has produced a number of important theoretical and applied findings, so his perspective on these issues is an important one. As a whole, the papers show that the field of eyewitness research is healthy, vibrant, occasionally contentious, and growing. We feel that Münsterberg and other pioneers would be proud of what they began, and we look forward to the next 100 years.

\section{Acknowledgments}

We are grateful to Jennifer Dysart and the John Jay College of Criminal Justice for organizing the "Off the Witness Stand" conference in New York City in March 2007, where the idea for this issue originated; and to Graham Davies, Bob Belli, and Martine Powell, the editors of Applied Cognitive Psychology, for their encouragement and support.

\section{References}

Banaji, M. R., \& Crowder, R. G. (1989). The bankruptcy of everyday memory. American Psychologist, 44, 1185-1193.

Benjamin, L. T. (2006). Hugo Münsterberg's attack on the application of scientific psychology. Journal of Applied Psychology, 91, 414-425.

Benton, T. R., McDonnell, S., Ross, D. F., Thomas, N., \& Bradshaw, E. (2007). Has eyewitness research penetrated the American legal system? In R. C. L. Lindsay, D. F. Ross, J. D. Read, \& M. P. Toglia (Eds.), Handbook of eyewitness psychology, Vol. 2: Memory for people (pp. 453-500). Mahwah, NJ: Erlbaum.

Bull, R. (1999). Police investigative interviewing. In A. Memon, \& R. Bull (Eds.), Handbook of the psychology of interviewing (pp. 279-292). Chichester, UK: John Wiley \& Sons. 
Clark, S. E. (2003). A memory and decision model for eyewitness identification. Applied Cognitive Psychology, 17, 629-654.

Clark, S. E., \& Davey, S. L. (2005). The target-to-foils shift if simultaneous and sequential lineups. Law $\mathcal{E}$ Human Behavior, 29, 151-172.

Gronlund, S. D. (2004). Sequential lineups: Shift in criterion or decision strategy? Journal of Applied Psychology, 89, 362-368.

Gronlund, S. D. (2005). Sequential lineup advantage: Contributions of distinctiveness and recollection. Applied Cognitive Psychology, 19, 23-37.

Kassin, S. M., Tubb, V. A., Hosch, H. M., \& Memon, A. (2001). On the 'general acceptance' of eyewitness testimony research: A new survey of the experts. American Psychologist, 56, 405-416.

Malpass, R. S. (2006). A policy evaluation of simultaneous and sequential lineups. Psychology, Public Policy, \& Law, 12, 394-418.

McQuiston-Surrett, D. E., Malpass, R. S., \& Tredoux, C. G. (2006). Sequential vs. simultaneous lineups: A review of methods, data, and theory. Psychology, Public Policy \& Law, 12, 137-169.

Meissner, C. A., Tredoux, C. G., Parker, J. F., \& MacLin, O. H. (2005). Eyewitness decisions in simultaneous and sequential lineups: A dual-process signal detection theory analysis. Memory \& Cognition, 33, 783-792.

Monahan, J., \& Walker, L. (2005). Social science in law (5th ed.). Westbury, NY: Foundation Press.

Münsterberg, H. (1898). The danger from experimental psychology. Atlantic Monthly, 81, 159-167.

Münsterberg, H. (1908). On the witness stand. New York: Doubleday.

Neisser, U. (1978). Memory: What are the important questions? In M. M. Gruneberg, P. E. Morris, \& R. N. Sykes (Eds.), Practical aspects of memory (pp. 3-24). London: Academic Press.

Neisser, U. (1991). A case of misplaced nostalgia. American Psychologist, 46, 34-36.

Penrod, S. D., \& Bornstein, B. H. (2007). Generalizing eyewitness reliability research. In R. C. L. Lindsay, D. F. Ross, J. D. Read, \& M. P. Toglia (Eds.), Handbook of eyewitness psychology, Vol. 2: Memory for people (pp. 529-556). Mahwah, NJ: Erlbaum.

Technical Working Group for Eyewitness Evidence. (1999). Eyewitness evidence: A guide for law enforcement. Washington, DC: U.S. Department of Justice.

Wells, G. L., \& Olson, E. A. (2002). Eyewitness identification: Information gain from incriminating and exonerating behaviors. Journal of Experimental Psychology: Applied, 8, 155-167.

Wiener, R. L., Hackney, A., Kadela, K., Rauch, S., Seib, H., Warren, L., et al. (2002). The fit and implementation of sexual harassment law to workplace evaluations. Journal of Applied Psychology, 87, 747-764.

Wigmore, J. H. (1909). Professor Münsterberg and the psychology of evidence. Illinois Law Review, 3, 399-445. 